\title{
Non-Granular Leukocyte
}

National Cancer Institute

\section{Source}

National Cancer Institute. Non-Granular Leukocyte. NCI Thesaurus. Code C12534.

A white blood cell that lacks cytoplasmic granules with an affinity for specific biological stains; typically, a lymphocyte, monocyte, or plasma cell. 